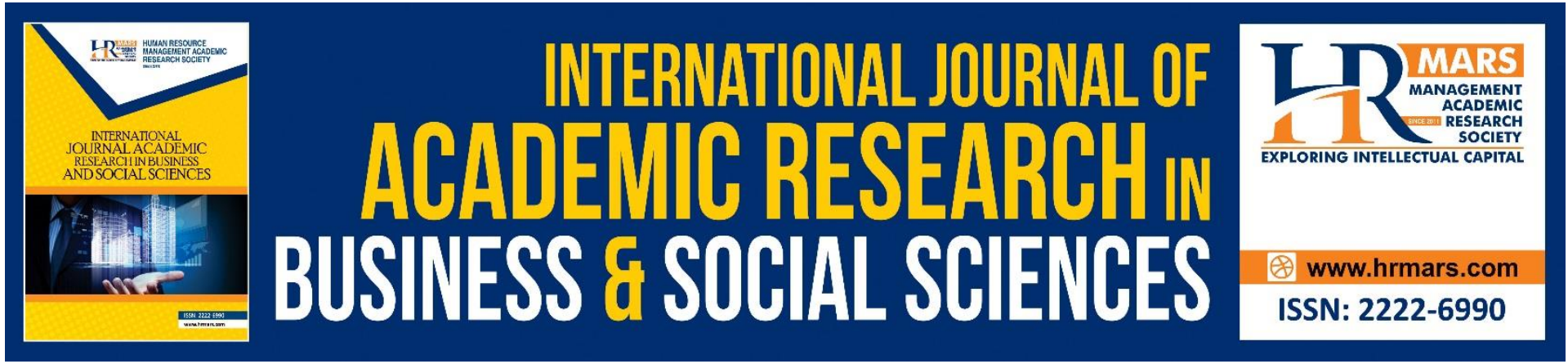

\title{
Macroeconomic Variables Influence on Stock Market Performance
}

Norazidah Shamsudin, Mohd Izuan Rosmi and Suhana Mohamed

To Link this Article: http://dx.doi.org/10.6007/IJARBSS/v11-i8/10507

DOI:10.6007/IJARBSS/v11-i8/10507

Received: 08 June 2021, Revised: 11 July 2021, Accepted: 06 August 2021

Published Online: 27 August 2021

In-Text Citation: (Shamsudin et al., 2021)

To Cite this Article: Shamsudin, N., Rosmi, M. I., \& Mohamed, S. (2021). Macroeconomic Variables Influence on Stock Market Performance. International Journal of Academic Research in Business and Social Sciences, 11(8), 1364-1376.

Copyright: @ 2021 The Author(s)

Published by Human Resource Management Academic Research Society (www.hrmars.com)

This article is published under the Creative Commons Attribution (CC BY 4.0) license. Anyone may reproduce, distribute, translate and create derivative works of this article (for both commercial and non-commercial purposes), subject to full attribution to the original publication and authors. The full terms of this license may be seen at: http://creativecommons.org/licences/by/4.0/legalcode

Vol. 11, No. 8, 2021, Pg. 1364 - 1376

Full Terms \& Conditions of access and use can be found at http://hrmars.com/index.php/pages/detail/publication-ethics 


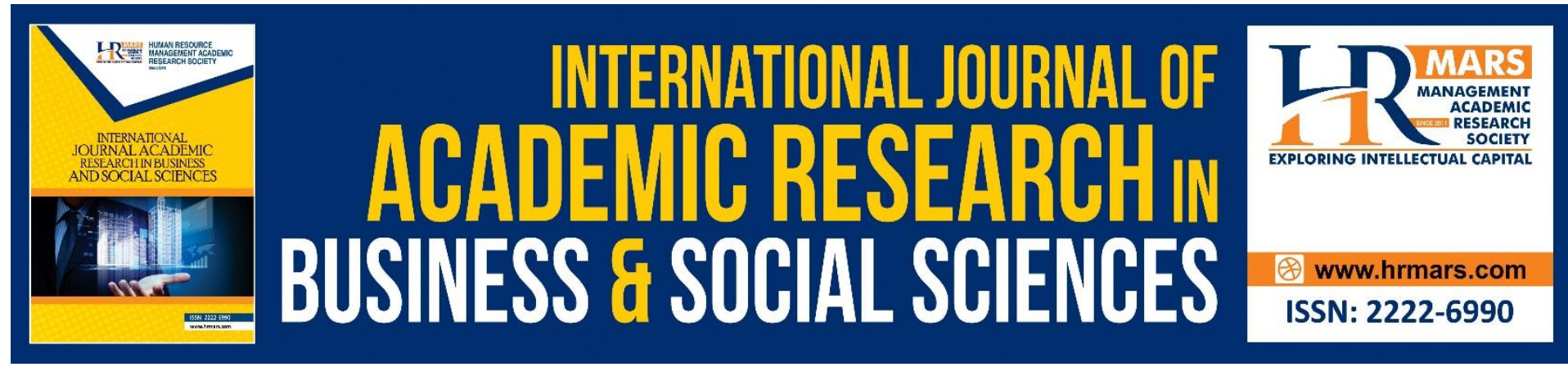

\section{Macroeconomic Variables Influence on Stock Market Performance}

\section{Norazidah Shamsudin ${ }^{1}$, Mohd Izuan Rosmi², and Suhana Mohamed $^{3}$}

${ }^{1}$ Faculty of Industrial Management, Universiti Malaysia Pahang, Malaysia, ${ }^{2}$ Faculty of Business and Management, Universiti Teknologi MARA, Johor Branch, Pasir, Gudang Campus, Johor Malaysia, ${ }^{3}$ Faculty of Business and Management, Universiti Teknologi MARA, Johor Branch, Pasir Gudang Campus, Johor Malaysia

Email: norazidah@ump.edu.my, izuanrosmi@gmail.com, suhan291@uitm.edu.my

\section{Abstract}

Investors should consider stock market performance when making an investment decision. Both economic and non-economic factors influence the stock market's performance. Previous research, primarily from developed markets, has revealed that macroeconomic factors significantly impact stock returns. Economic forces are used in this paper to investigate the significant relationship between selected macroeconomic variables, the Malaysian stock return index for the financial sector, and the Bursa Malaysia Finance Services Index. The macroeconomic variables examined are inflation (INF), money supply (M.S.) and the real effective exchange rate (REER). This study's sample consists of 164 timeseries observations. The observations are annual secondary data obtained from the World Bank, Index Mundi, and the Malaysian Bureau of Statistics from January 1979 to December 2019. Several regression analyses and econometric tests were performed with the interactive software package E-Views 11 . The findings of this research paper provide an initial overview and can serve as a valuable foundation for investors' and policymakers' respective investment strategies and policies.

Keywords: Stock market, Inflation, Money Supply, Real Effective Exchange Rate, Malaysia

\section{Introduction}

Investors have long used stock exchanges to reduce risk and mobilize financial resources. These unintended capital inflows into the economy have unintended consequences for economic growth. Individuals will have more options as the economy grows. As a result, what happens in the stock market has an enormous impact on people's lives. Increased stock market activity helps to stimulate economic growth. According to Rasheed et al. (2020), Malaysian stock prices have a long-term relationship with the interest rate, inflation, money supply, oil price, and exchange rate. As a result, the stock market's liquidity is critical in raising capital from investors. 
Investors consider macroeconomic variables that influence the stock exchange's assessment when evaluating a stock. Loan fees, trading rates, expansion, inflation rate, money supply, and GDP are examples of macroeconomic factors influencing financial exchange representation. Several direct studies on the relationship between macroeconomics and stock prices have been conducted. According to the findings of these studies, there is a strong correlation between macroeconomic conditions and stock prices (Rasheed et al., 2020).

The macroeconomic variables are critical in assessing the stock market's performance. Investors benefit from analyzing investments in light of current stock market trends. Furthermore, because macroeconomic variables coexist, investors would have to decide when to enter or exit the stock market (Bhuiyan \& Chowdury, 2020). As a result, the primary goal of the research project is to identify and investigate the effects of macroeconomic variables on the development of emerging markets in both short- and long-term dynamics (Bhuiyan \& Chowdury, 2020).

\section{Research Background}

Due to the country's economic growth performance, Malaysia is a potential country for investors looking for a new business opportunity. Over the last few decades, Malaysia's stock exchange has grown in tandem with the country's rapid economic growth. Because the Malaysian stock exchange is directly influenced by economic growth, sound macroeconomic management ensures financial development stability and social advancement.

In December 1976, the Kuala Lumpur Stock Exchange took over the Berhad operations of the Kuala Lumpur Stock Exchange. To better reflect its global position and current trend, it was renamed Bursa Malaysia Berhad in 2004. Malaysian Insider News reports that the Malaysian stock market is on the verge of a bubble in 2013, owing to a significant increase in credit, resulting in insufficient investment. Furthermore, Trading Economics' Malaysia Stock Exchange (S.M.) data shows that the pre-global recession low reached 1,219.72 in the 52 weeks from 2019 to 2020.

Before making any investment, investors must conduct research and gather accurate information in order to calculate risk. Further research assists investors in making investment decisions, particularly following the Asian financial crisis and the implementation of capital controls in Malaysia. Investors would seek investments that would allow them to achieve their goal of increasing capital gains while also contributing to the investment's long-term profitability and growth (Shamsudin, Mahmood \& Ismail, 2013). Dealers and brokers assist customers with new business ventures or investments to ensure that the investment in the resource stream is profitable and productive. Nonetheless, macroeconomic factors play a significant role in Malaysian stock market valuation.

The macroeconomic variable, which includes the rate of inflation, the money supply, and the real effective rate, is the independent variable in this study. Furthermore, the Malaysian stock market's development is the dependent variable in this study.

\section{Stock Market Development}

Malaysian Stock Exchange History: For nearly 80 years, the Bursa Malaysia Berhad has been a significant participant in global stock markets. Malaysia's first sanctioned securities trading 
organization was the Singapore Stockbrokers' Association, a private organization founded in 1930. In 1937, the Malaysian Exchange Association was renamed the Malayan Stockbrokers' Association, but shares were not publicly traded. The Malayan Stock Exchange, a Malaysian public market, opened to public stock trading for the first time in 1960. As a result, the Malayan Stock Exchange anticipated the Malay securities market that exists today. Malaysian Stock Exchange was renamed the Stock Exchange of Malaysia in 1964.

The expansion of the stock market is an important component of overall development. The stock market is a leading indicator of an economy's financial health. It reflects a country's investor mindset. The stock exchange is an important platform for companies to raise capital, while investors have a stake in the organization's trading transactions.

According to Pan and Mishra (2018), economic factors alone do not guarantee stock market performance. As a result, the author chose to study in China because a large country's economy, such as China's, is influenced by factors other than the stock market. On the other hand, the Total Spillover Index found no significant differences in terms of return and volatility between the Chinese stock market and macroeconomic variables (Abbas et al., 2019).

Several macroeconomic news surprises in the U.S. had an immediate and significant impact on Canadian index returns and volatility (Hussain \& Omrane, 2020). During the 2008 U.S. recession, they had a significant and relatively large impact on Canadian stock returns. Overall, the findings from high-frequency data support the existing literature, which is primarily based on daily frequency, by demonstrating that U.S. macroeconomic fundamentals link Canadian and U.S. financial markets.

\section{Inflation Rate}

In the economy, inflation is defined as an increase in the cost of goods and services. It is a continuous increase in an economy's overall value. On the other hand, inflation denotes an increase in the average cost of basic goods when the cost of goods and services rises. As a result, the annual rate of change in the general level of value is expressed as a percentage of the inflation rate.

According to Lee and Kim (2020), there has been a statistically significant increase in the negative relationships between realized correlations and monetary performance differentials (interest and inflation differentials) in the E.U. sample since the beginning of EMU. Countries. The results strongly suggest that more significant monetary similarities between the E.U. Countries were an important engine for the increased integration of the E.U. Stock markets. Volatility spillover effects (i.e. contagion effects) would spill over rather than return in times of crisis.

The hypothesis that the Indian stock market reflects the informational content of the inflation announcement and that there is no abnormal return was then rejected by Singh and Padmakumari (2020). Inflationary pressures undermine managers' ability to make valueadded investment decisions based on stock market data. Companies in high-inflationary environments are significantly less vulnerable to stock price fluctuations than companies in low-inflationary environments (Farooq \& Ahmed, 2018). 
An empirical analysis of the U.S. stock market from 1791 to 2015 in a time-varying framework, according to Antonakakis, Gupta, and Tiwari (2017), shows that the correlation is significantly positive in the 1840s, 1860s, 1930s, and 2011s otherwise. According to these findings, actual stock returns and inflation, in general, are inversely related; however, lower inflation rates do not guarantee a healthier stock market.

Jamaludin, Ismail, and Manaf (2017) concluded that inflation was a significant influence on stock market returns in the selected ASEAN countries of Singapore, Malaysia, and Indonesia by analyzing the effects of macroeconomic variables on the returns of conventional and Islamic stock markets using monthly data from January 2005 to December 2015 and the panel's least squares method. Inflation has a greater impact on stock market returns and is inversely related to them.

Laichena and Obwogi (2015) discovered in East Africa that inflation has a positive and significant relationship with stock returns. Inflationary pressures are caused by an increase in the money supply, which leads to an increase in investment. From 2005 to 2014, stock exchange data from three East African countries (Kenya, Uganda, and Tanzania) were used in this analysis. Megaravalli and Sampagnaro (2018), on the other hand, discovered no significant long-term relationship and no significant short-term relationship between inflation and the ASEAN countries of India, China, and Japan.

\section{Money Supply}

Economists study the flow of money in the economy and devise policies to control interest rates and increase or decrease the flow of money. Increasing the supply of cash can help lower interest rates, resulting in higher investments and more cash in buyers' hands, increasing spending. It is classified into several types of liquidity. For example, different types of cash deliveries, $\mathrm{M} 0, \mathrm{M} 1, \mathrm{M} 2$, and $\mathrm{M} 3$, are commonly referred to as M.S. designated, depending on the type and size of the instrument being kept. Furthermore, cash reflects the various types of liquidity that any type of cash has in the economy. According to Bhuiyan and Chowdury (2020), in the United States, the stock market and the money supply (M1) correlate positively, but not in Canada. The results, however, are not surprising given that signals are being carried over from the U.S. market to other international markets.

Picha (2017) investigated the effect of money supply on the stock market by looking at the portfolio balance channel as a monetary policy transmission mechanism, similar to the National Cash Flow Account, and using assets from U.S. household portfolios as key data resources, as Johansen's cointegration methodology does. The money supply exercise has a 6-month lag and can be seen in the long-term relationship, and all practical asset classes can positively influence the price of the S\&P 500 .

According to Jamaludin et al. (2017), an analysis of the influence of macroeconomic variables on the returns of conventional and Islamic stock markets in their selected ASEAN countries reveals that the money supply (M.S.) has no significant influence on the stock market return. From January 2005 to December 2015, monthly data from Singapore, Malaysia, and Indonesia were examined using least squares panel regression techniques. 


\section{Exchange Rate}

The actual exchange rate compares the prices of imported and domestic goods. A currency's successful exchange rate is then normalized. Furthermore, successful currency exchange is used to assess how a currency fluctuates with other currencies and global trade. Finally, weights are calculated by comparing a country's relative trade balance to the index.

Shortly after 2018, Erdogan et al (2020) discovered bidirectional volatility spillovers between the Islamic stock market and the foreign exchange market. This discovery demonstrated that the degree of interdependence between the Islamic stock market and the exchange rate market has grown, especially since 2018. Megaravalli and Sampagnaro (2018) studied data from 2008 to 2016, and the pooled group mean estimates show that the exchange rate has a long-term positive and significant relationship with the stock market for India, China, and Japan as a whole.

Rising exchange rates, which represent an increase in the value of the U.S. dollar, will reduce stock returns on East African stock exchanges. According to Laichena and Obwogi (2015), the exchange rate has a significantly inverse relationship with East African stock returns. This study used stock exchange data from three East African countries (Kenya, Uganda, and Tanzania) from 2005 to 2014.

Jamaludin and colleagues (2017). Hoque and Yakob (2017) examined and demonstrated, using data from 1981 to 2016, that exchange rates interact with one another and positively influence the relationship between stock market development and economic development in Malaysia. Monthly data from January 2005 to December 2015 were used to calculate returns in three ASEAN countries: Singapore, Malaysia, and Indonesia, using least squares panel regression techniques.

In contrast to Mahapatra and Bhaduri (2019), the Indian exchange rate and stock market development have positively correlated over the last four years (2012-2016). The study of the macroeconomic drivers of the Philippine stock market using PSEI data from 2009 to 2014 reveals that the exchange rate had a positive impact on the short-term relationship (Ho \& Odhiambo, 2018). It demonstrated market inefficiency in the context of the stock market.

\section{Research Methodology}

The goal of this research is to determine the significance of the selected variables, inflation rate (INF), money supply (M.S. ), and real effective exchange rate (REER), on the performance of the Malaysian stock market (S.M.). This study's sample consists of 164 time-series observations. The observations are secondary data collected on an annual basis from the World Bank, Index Mundi, and the Malaysian Statistical Office from January 1979 to December 2019. Several regression analyses and econometric tests are performed with the interactive software package E-views 11 to achieve the goal. 
INTERNATIONAL JOURNAL OF ACADEMIC RESEARCH IN BUSINESS AND SOCIAL SCIENCES Vol. 11, No. 8, 2021, E-ISSN: 2222-6990 @ 2021 HRMARS

\begin{tabular}{|l|l|l|l|}
\hline Variables & Proxy & Explanation & Units \\
\hline $\begin{array}{l}\text { Bursa Malaysia Finance Services } \\
\text { Index }\end{array}$ & S.M. & $\begin{array}{l}\text { Composite market index in Index } \\
\text { Malaysia on financial sector }\end{array}$ & $\begin{array}{l}\text { General fall in the value of } \\
\text { money, and increase in prices }\end{array}$ \\
\hline Inflation & INF & Money circulation in Malaysia & R.M. Millions \\
\hline Money Supply & MS & $\begin{array}{l}\text { Exchange rate of Ringgit } \\
\text { Malaysia against U.S. Dollar }\end{array}$ & R.M. \\
\hline Real Effective Exchange Rate & REER &
\end{tabular}

Table 1: Summary of Variables

The data was first analyzed using descriptive statistics to determine central tendency and dispersion. Among the measurements are the mean, minimum, maximum, kurtosis, and skewness of the data or variables. When the $p$-value falls below the $5 \%$ level of significance, we conclude that the variable's data are stationary. To examine data stationarity, the unit root test was also used. Furthermore, the Augmented Dickey-Fuller (ADF) and Phillips-Perron (P.P.) unit root tests are used to determine data stationarity testing (Ajewole, Adejuwon, \& Jemilohun, 2020; Aktivani, 2020; Escobari, Garcia, \& Mellado, 2017).

A correlation test was also run to look at how the dependent and independent variables correlated. Furthermore, the correlation between the independent variables should be established. The correlation is examined to see if it is between -1.0 and +1.0 , indicating either weak or strong variation in one variable when another variable varies.

Multiple regression analysis is used in this study to examine the direction and significance of the relationship between the independent variable and the dependent variable. The regression results are analyzed using the t-test, $f$-test, and Durbin Watson statistics. In the analysis, the regression coefficients and $p$-values show the importance of each independent variable in predicting the dependent variable.

The following is the general regression model for the study:

$S . M . i=B_{0}-B_{1} I N F_{i}+b_{2} M S_{i}+b_{3} R E E R_{i}+\varepsilon_{i}$

S.M. is the dependent variable in equation (1), while INF, MS, and INF are the independent variables that S.M. influences. The values 0 and I represent the constant value and the error term or residual, respectively. In the meantime, the numbers 1, 2, and 3 represent the beta coefficients of each independent variable. The beta coefficient expresses the magnitude of an influence on a positive or negative relationship with the dependent variable.

\section{Findings and Discussion}

This study investigates the relationship between selected macroeconomic variables and the performance of Bursa Malaysia using three independent variables (inflation, money supply, and real effective exchange rate) and one dependent variable (Bursa Malaysia) (stock market performance). 


\section{Descriptive Analysis}

Table 2: Descriptive Statistics of Selected Factors affecting Stock Market in Malaysia

\begin{tabular}{lllll}
\hline & S.M. & INF & MS & REER \\
\hline Mean & 2.882330 & 1.873049 & 4.943064 & 2.056761 \\
Median & 2.909732 & 1.899285 & 4.972357 & 2.014238 \\
Maximum & 3.271135 & 2.084444 & 5.672490 & 2.264480 \\
Minimum & 2.313002 & 1.589037 & 3.998689 & 1.930146 \\
Std. Dev. & 0.287881 & 0.141645 & 0.534154 & 0.097526 \\
Skewness & -0.353751 & -0.212280 & -0.116415 & 0.724365 \\
Kurtosis & 1.956995 & 1.892939 & 1.682526 & 2.322143 \\
\hline
\end{tabular}

Table 2 displays the descriptive statistical results for the dependent (S.M.) and independent variables (INF, MS, and REER) from 1979 to 2019. As shown in the table above, the mean of S.M., INF, MS, and REER are 2.882330, 1.873049, 4.943064, and 2.056761, respectively. S. M. has a maximum of 3.271135 and a minimum of 2.313002. Furthermore, REER has the lowest standard deviation of 0.097526 when compared to other variables. Furthermore, because the skewness is greater than zero, S.M., INF, and M.S. are skewed to the right. REER, on the other hand, is skewed to the left because the skewness exceeds zero. Because the kurtosis is less than three, S.M., INF, MS, and REER data are less volatile.

Unit Root Test

Table 3: Result of Unit Root Test - Augmented Dickey-Fuller (ADF)

\begin{tabular}{lclcl}
\hline Variable & $\begin{array}{c}\text { Level } \\
\text { No Trend }\end{array}$ & Trend & $\begin{array}{c}\mathbf{1}^{\text {st }} \text { Different } \\
\text { No Trend }\end{array}$ & Trend \\
\hline S.M. & 0.3414 & 0.0805 & $0.0000^{*}$ & $0.0000^{*}$ \\
INF & $0.0301^{*}$ & 0.0651 & $0.0077^{*}$ & $0.0198^{*}$ \\
MS & 0.4720 & 0.5841 & $0.0011^{*}$ & $0.0055^{*}$ \\
REER & 0.6616 & 0.6359 & $0.0003^{*}$ & $0.0021^{*}$ \\
\hline
\end{tabular}

Notes: * indicates that the variables are stationary at 5 percent significance level.

Table 3 displays the results of the ADF unit root test. All variables are significant at the first different level, according to the table above. All variables have values that are less than $5 \%$ of the significant level. At the $5 \%$ level of significance, the first difference in all variables is significant. As a result, the null hypothesis can be rejected. 


\section{Pearson Correlation Analysis}

Table 4: Pearson Correlation Analysis

\begin{tabular}{l|llll}
\hline \hline $\begin{array}{l}\text { Correlation } \\
\text { Probability }\end{array}$ & \multicolumn{1}{l}{ S.M. } & INF & MS & REER \\
\hline S.M. & 1.000000 & & & \\
INF & ---- & & & \\
& 0.904441 & 1.000000 & & \\
0.0000 & ---- & & \\
MS & 0.931683 & 0.989989 & 1.000000 & \\
& 0.0000 & 0.0000 & ---- & 1.000000 \\
REER & -0.830995 & -0.913941 & -0.894278 & ---- \\
\hline \hline
\end{tabular}

Table 4 depicts the relationship in the regression model between the dependent variable and the independent variables. The $p$-values for INF and M.S. show a strong positive correlation, whereas REER shows a strong negative correlation. All variables are statistically significant with a value of 0.000 , which is less than $1 \%$ of the significance level. As a result, the null hypothesis is rejected, indicating that INF and M.S. have a significant positive relationship with S.M. REER, on the other hand, has a significant inverse relationship with S.M. As a result, the stock market has a linear relationship or correlation with inflation, the money supply, and the exchange rate.

\section{Multiple Regression Analysis}

A regression analysis was performed, and the results are summarised in table 5 and in equation (2) below:

Table 5: Result of Multiple Regression

\begin{tabular}{lllll}
\hline \hline Variable & Coefficient & Std. Error & t-Statistic & Prob. \\
\hline \hline C & 2.951072 & 1.479774 & 1.994273 & 0.0535 \\
INF & -2.259678 & 0.890163 & -2.538499 & 0.0155 \\
MS & 1.024040 & 0.214072 & 4.783623 & 0.0000 \\
REER & -0.436682 & 0.407755 & -1.070941 & 0.2911 \\
\hline \hline R-squared & 0.887628 & Mean dependent var & 2.882330 \\
Adjusted R-squared & 0.878517 & S.D. dependent var & 0.287881 \\
F-statistic & 97.42121 & Durbin-Watson stat & 0.997261 \\
Prob(F-statistic) & 0.000000 & & & \\
\hline \hline
\end{tabular}

According to Table 5 on the result of the multi-regression test, the probabilities for INF, MS, and REER are $0.0155,0.0000$, and 0.2911 , respectively. Both the INF and M.S. values are less than $5 \%$ of the significance level. As a result, the null hypothesis is invalid. As a result, the relationship between INF and M.S. and the dependent variable can be deduced. As a result, 
the results of the regression analysis can be transformed into an econometric equation as follows:

$$
\text { S.M. } i=2.951072-2.259678\left(\mathrm{INF}_{i}\right)+1.024040\left(\mathrm{MS}_{i}\right)-0.436682\left(\mathrm{REER}_{i}\right)+\varepsilon_{i}
$$

Equation (2) represents the level of influence of INF, MS, and REER on the S.M. The equation shows that M.S. has a positive relationship with the Malaysian stock market, whereas INF and REER have a negative relationship. It can be explained by a $1 \%$ decrease in inflation and a $0.436682 \%$ decrease in real effective interest rate, which will increase stock market performance by $2.259678 \%$ and $0.436682 \%$, respectively. In contrast, a $1 \%$ increase in the money supply raises the stock market's performance by $1.024040 \%$.

The F-statistic has a p-value of 0.000000 , as shown in Table 5. It is less than the 0.05 level of significance. As a result, the null hypothesis is rejected, suggesting that the model is fit at a $5 \%$ significance level. Overall, this indicates that Malaysia's inflation (INF), money supply (M.S.), and exchange rate (REER) are all in sync with the stock market, indicating a strong relationship.

Furthermore, the R2 value in Table 5 is 0.887628 , implying that the selected macroeconomic variables, namely inflation (INF), money supply (M.S.), and exchange rate (REER), account for $88.76 \%$ of the Malaysian stock market. Other factors account for the remaining 11.24 percent of the variation. Furthermore, the adjusted R2 value is 0.878517 . This value indicates that the selected macroeconomic variables, namely inflation (INF), money supply (M.S.), and exchange rate, explained 87.85 percent of the stock market (REER).

\section{Conclusion and Recommendation}

The conclusion and recommendation were discussed in the following sections.

\section{Conclusions}

This study backs up the findings of Lee and Kim (2020), Singh and Padmakumari (2020), and Jamaludin, Ismail, and Manaf (2017) that there is a negative significant correlation between the development of the Malaysian stock market and inflation. According to the findings, Malaysian inflation (INF) has a negative but significant correlation with stock market developments. Rising inflation will have a negative impact on stock market growth, implying. In other words, as inflation rises, stock market performance suffers.

According to the findings, the Malaysian stock market's development appears to positively correlate with the money supply. This means that any change in the money supply will have an impact on the Malaysian stock market's development. This implies that an increased money supply will fuel stock market growth. This implies a similar result in Malaysia, where an increase in the money supply would stimulate growth in the Malaysian stock market. The findings are consistent with those of Bhuiyan and Chowdury (2020), who discovered a positive significant correlation between money supply and stock market development when studying factors influencing the stock market development in different countries.

The analysis reveals no statistically significant relationship between the exchange rate and the development of the Malaysian stock market. This means that changes in the exchange rate will not affect the stock market's performance. The findings are consistent with those of Mwaanga and Njebele (2017), who discovered a negative and insignificant long-term effect 
of REER on stock index with Auto Regression Distribution Lag (ARDL) and insignificant shortterm effects with the Vector Error Correction Model (VECM). Similarly, Gokmenoglu, Eren, and Hesami (2021) discovered that exchange rate fluctuations did not affect the performance of the country's stock market unless certain market conditions were met.

The purpose of this research is to discover a statistically significant relationship between all independent variables, namely the inflation rate (INF), money supply (M.S.), and real effective exchange rate (REER), and the dependent variable stock market development (S.M.) can be found in Malaysia. The study examined annual data from 1979 to 2019 and included 164 observations. It turns out that two independent variables, INF and REER, have an inverse relationship with S.M., whereas M.S. has a positive relationship with S.M. As a result, in order to stimulate the Malaysian stock market, inflation and the real effective exchange rate should be reduced while the money supply increased.

\section{Contribution}

The study adds to the theoretical understanding of the relationship between inflation, money supply, and the real effective exchange rate on Malaysian stock exchange performance. Based on 41 years of data, it is suggested that the Malaysian stock market is well predicted by the money supply and inflation, but not by the real effective exchange rate. Future researchers may consider including more macroeconomic variables as independent variables or any control variable to confirm further the significant relationship between the Malaysian real effective exchange rate and stock performance.

Furthermore, the outcome may provide the investor with an input to consider the major macroeconomic variables (increase or decrease in inflation and money supply) as additional information before investment planning or decision-making. Furthermore, if necessary, the research could aid in adjusting monetary policy by assisting Malaysia in improving its equity market performance.

\section{Recommendation}

The more independent variables used to investigate a relationship, the more results and additional information or facts can be obtained. More independent variables, such as unemployment, GDP, export, import, and interest rate, are expected to be used by future researchers. When these variables are considered, the researcher gains a better understanding of them.

In the future, researchers are encouraged to experiment with different data structures, such as quarterly, monthly, or weekly. This is because different independent variables can react differently to different frequencies. Secondary data collection, on the other hand, is almost always difficult. Many researchers run into a problem or a limitation when gathering data. As a result, when collecting secondary data, you may need to consider and overcome this limitation.

This study was carried out by the researcher using data from Malaysia. Because the determining variables in Malaysia differ from those in many other countries, research findings can vary greatly. Other countries' data, such as Thailand, Singapore, and Vietnam, can help 
future researchers broaden their horizons. Future research will also compare the U.S. stock market to that of other countries.

\section{Corresponding Author}

Suhana Mohamed

Department of Finance, Faculty of Business and Management, Universiti Teknologi MARA, Johor Branch, Pasir Gudang Campus, Jalan Purnama, Bandar Seri Alam, 81750 Masai, Johor, Malaysia.

Email: suhan291@uitm.edu.my

\section{References}

Abbas, G., Bashir, U., Wang, S., Zebende, G. F., \& Ishfaq, M. (2019). The return and volatility nexus among stock market and macroeconomic fundamentals for China. Physica A: Statistical Mechanics and its Applications, 526, 121025. https://doi.org/10.1016/j.physa.2019.04.261

Ajewole, K. P., Adejuwon, S. O., \& Jemilohun, V. G. (2020). Test for stationarity on inflation rates in Nigeria using Augmented Dickey-Fuller Test and Phillips-Persons Test. IOSR Journal of Mathematics (IOSR-JM), 16(3), 11-14. https://doi:10.9790/5728-1603031114

Aktivani, S. (2020). Uji stasioneritas data inflasi Kota Padang periode 2014-2019. Statistika, 20(2), 83-90. https://doi:10.29313/jstat.v20i2.7257

Antonakakis. N, Gupta, R., \& Tiwari. A (2017). Has the correlation of inflation and stock price changed in the United States over the two centuries? Research in International Business and Finance 42, 1-8. https://doi:10.1016/j.ribaf.2017.04.005

Bhuiyan, E. M., \& Chowdury, M. (2020). Macroeconomic variables and stock market indices: Asymmetric dynamics in the U.S. and Canada. The Quarterly Review of Economics and Finance, 77, 62-74. https://doi.org/10.1016/j.qref.2019.10.005

Erdogan, S., Gedikli, A., \& Cevik, E. I. (2020). Volatility spillover effects between Islamic stock markets and exchange rates: Evidence from three emerging countries. Borsa Istanbul Review, 20(4), 322-333. https://doi.org/10.1016/j.bir.2020.04.003

Escobari, D., Garcia, S., \& Mellado, C. (2017). Identifying bubbles in Latin American equity markets: Phillips-Perron-based tests and linkages. Emerging Markets Review, 33, 90101. https://doi.org/10.1016/j.ememar.2017.09.001

Farooq, O., \& Ahmed, N. (2018). Does inflation affect sensitivity of investment to stock prices? Evidence from emerging markets. Finance Research Letters, Elsevier, 25, 160-164. https://doi.org/10.1016/j.frl.2017.10.019

Gokmenoglu, K., Eren, B. M., \& Hesami, S. (2021). Exchange rates and stock markets in emerging economies: New evidence using the quantile-on-quantile approach. Quantitative Finance and Economics, 5(1), 94-110. https://doi.org/10.3934/QFE.2021005

Ho, S. Y., \& Odhiambo, N. M. (2018). Analyzing macroeconomic drivers of stock market development in the Philipines. Cogent Economic \& Finance, 6(1), 1-18. https://doi.org/10.1080/23322039.2018.1451265

Hoque. M. E., \& Yakob, N. A. (2017). Revisiting stock market development and economic growth nexus: The moderating role of foreign capital inflows and exchange rates. Cogent Economics \& Finance, 5(1), 1-17.

https://doi.org/10.1080/23322039.2017.1329975 
Hussain, S. M., \& Omrane, W. B. (2020). The effect of U.S. macroeconomic news announcements on the Canadian stock market: Evidence using high-frequency data. Finance Research Letters, 38, 101450. https://doi.org/10.1016/j.frl.2020.101450

Jamaludin, N., Ismail, S., \& Manaf, S. A. (2017). Macroeconomic variables and stock market return panel analysis from selected ASEAN countries. International Journal of Economics and Financial Issue, 7(1), 37-45. https://ideas.repec.org/a/eco/journ1/2017-01-07.html

Laichena. K. E., \& Obwogi, T. N. (2015). Effects of macroeconic variables on stock returns in the East African community stock exchange market. International Journal of Education and Research, 3(10), 305-320. https://ijern.com/journal/2015/October-2015/24.pdf

Lee, H., \& Kim, H. (2020) Time varying integration of European stock markets and monetary drivers. Journal of Empirical Finance, 58, 369-385. https://doi.org/10.1016/j.jempfin.2020.07.004

Mahapatra, S., \& Bhaduri, S. N. (2019). Dynamics of the impact of currency fluctuations on stock markets in India: Assessing the pricing of exchange rate risks. Borsa Istanbul Review, 19(1), 15-23. https://doi.org/10.1016/j.bir.2018.04.004

Megaravalli, A. V., \& Sampagnaro, G. (2018). Macroeconomic indicators and their impact on stock market in ASIAN 3: A pooled mean group approach. Cogent Economics \& Finance 6(1), 1-14. https://doi.org/10.1080/23322039.2018.1432450

Mwaanga, C., \& Njebele, N. (2017). The long-run and short-run relationship between the exchange rates and stock market prices. Journal of Financial Risk Management, 6(4), 315-324. https://doi.org/10.4236/jfrm.2017.64023

Pan, L., \& Mishra, V. (2018). Stock market development and economic growth: Empirical evidence from China. Economic Modelling, 68, 661-673. https://doi.org/10.1016/j.econmod.2017.07.005

Picha, V. (2017). Effect of money supply on the stock market. Acta Universitasis Agriculturae et Silviculturae Mendelianae Brunensis, 65(2), 465-472. https://doi.org/10.11118/actaun201765020465

Rasheed, A., Saeedi, M., Gebril, N., \& Hariraj, K. (2020). Impact of macroeconomic variables on stock market of Malaysia. International Journal of Psychosocial Rehabilitation, 24(2), 1205-1204. https://doi.org/10.37200/IJPR/V24I2/PR200420

Shamsudin, N., Mahmood, W. M. W., \& Ismail, F. (2013). The performance of stock and the indicators. International Journal of Trade, Economics and Finance, 4(6), 409-413. https://doi.org/10.7763/IJTEF.2013.V4.327

Singh, G., \& Padmakumari, L. (2020). Stock market reaction to inflation announcement in the Indian stock market: A sectoral analysis. Journal Cogent Economics \& Finance, 8(1), 122. https://doi:10.1080/23322039.2020.1723827 